\title{
Grenville Foreland Deformation and Sedimentation in Southwest Ohio Indicated by Reprocessed Seismic Reflection Profiles near Middletown, Ohio, USA
}

DAVID J. PETERMAN ${ }^{1}$, ERNEST C. HAUSER, and DOYLE R. WATTS, Department of Earth and Environmental Sciences, Wright State University, Dayton, OH, USA.

ABSTRACT. The late Mesoproterozoic to early Neoproterozoic Middle Run Formation contains vital information about the crustal evolution of the North American Craton. Four reprocessed seismic reflection lines in the vicinity of the AK Steel facility in Middletown, Ohio, provide new insights into the structural and depositional setting of the Middle Run Formation in this region. A residual statics solution improved the resolution and coherency of reflections in these profiles that underlie the Cambrian Mount Simon Sandstone. Reprocessing revealed gently inclined, west-southwest-dipping reflectors and the occurrence of an angular unconformity between the Middle Run Formation and the overlying Paleozoic strata. The weak and discontinuous seismic reflection character of the Middle Run Formation in these seismic lines overlies a sequence of stronger parallel reflections that are like those observed on the eastward ODNR-1-88 seismic line located near core hole DGS 2627, the stratotype of the Middle Run Formation. This inferred thickness indicates that the basin in which the Middle Run Formation was deposited ranges from at least 670 to $1,128 \mathrm{~m}(2,200$ to 3,700 ft) deep at the AK Steel area and dips gently west-southwest, which is in contrast with the moderate easterly dip observed on the ODNR-1-88 seismic line to the northeast. Correlation of these features across the $10 \mathrm{~km}$ (approximately $6 \mathrm{mi}$ ) cross-strike gap between the AK Steel lines and the ODNR-1-88 seismic line suggests the presence of a reverse fault with approximately $792 \mathrm{~m}(2,600 \mathrm{ft})$ of estimated vertical displacement. A regional cross section-including the WSU 1990 seismic line eastward of the ODNR-1-88 line-exhibits a faulted west-verging asymmetric syncline in near proximity to the Grenville Front. This cross section also shows that deformation of the Middle Run Formation and the underlying layered sequence exhibits a consistent tectonic style of reverse faulting and folding that developed in response to Grenville Front tectonism.

\section{Purpose of Study}

\section{INTRODUCTION}

In 1991, four seismic reflection lines were acquired in the vicinity of the AK Steel plant (formerly ARMCO Steel) near Middletown, Ohio (Fig. 1A). The lines were required by the Ohio Environmental Protection Agency (OEPA) as a condition for permitting 2, Class I injection wells into the Cambrian Mount Simon Sandstone. These 4 lines were originally intended to examine the structural character of the subsurface rocks in and near the proposed injection wells and target horizon. The original processing of the AKSteel lines was conducted by Woods Geophysical Inc. and initial interpretations were made by Envirocorp Services \& Technology Inc. However, processing and interpretation of deeper structural features, and their regional extent, was not within the scope of the original project.

\footnotetext{
${ }^{1}$ Address correspondence to David J. Peterman, Department of Earth and Environmental Sciences, Wright State University, Brehm 272D, 3640 Colonel Glenn Hwy, Dayton, OH 45435, USA. Email: peterman.10@wright.edu
}

The purpose of the current study is to (1) reprocess the AK Steel seismic lines with emphasis on better understanding the seismic reflections below the Paleozoic sedimentary cover of the region, and (2) examine the relationship between the 1991 AK Steel lines and 2 previously acquired seismic lines, ODNR-1-88 and Wright State University 1990 (WSU 1990), located eastward of the AK Steel plant (Fig. 1B). Interpretation of the reprocessing results, combined with recently published age dates for the Precambrian Middle Run Formation and timing of regional tectonic events, allow analyses of structural and sedimentological elements in the area-plus plausible explanations for the sedimentary provenance, age of deposition, and timing of deformational events associated with the Middle Run Formation in southwest Ohio.

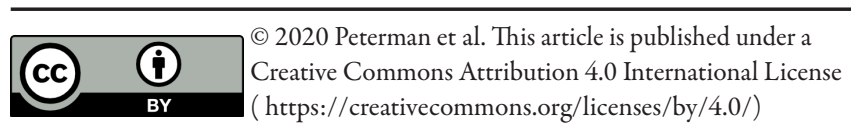




\section{Discovery of the Middle Run Formation}

In 1988, the Ohio Department of Natural Resources (ODNR), Division of Geological Survey (DGS) drilled a continuous stratigraphic test core hole (DGS 2627) (Fig. 1B) in Warren County, Ohio. The core penetrated the expected Paleozoic sedimentary sequence but, at a depth of $1,058 \mathrm{~m}$ $(3,470 \mathrm{ft})$, unexpectedly discovered a previously unrecognized red lithic arenite below the Cambrian Mount Simon Sandstone (Shrake et al. 1990). Later, core DGS 2627 and the red lithic arenite were designated as the stratotype for a newly defined Precambrian sedimentary unit - the Middle Run Formation (Shrake 1991).
Subsequent to the drilling of DGS 2627, Seismic Line ODNR-1-88 was acquired to better understand the geological setting of the newly discovered Middle Run Formation and its vicinity. The resulting seismic line revealed the Middle Run Formation is part of a steep eastward-dipping layered sequence that makes an angular unconformity with the overlying, flat-lying, Mount Simon Sandstone. The angular unconformity beneath the Mount Simon Sandstone ruled out the possibility that the Middle Run Formation was a previously undefined facies of the Mount Simon Sandstone (Shrake et al. 1990; Shrake 1991).

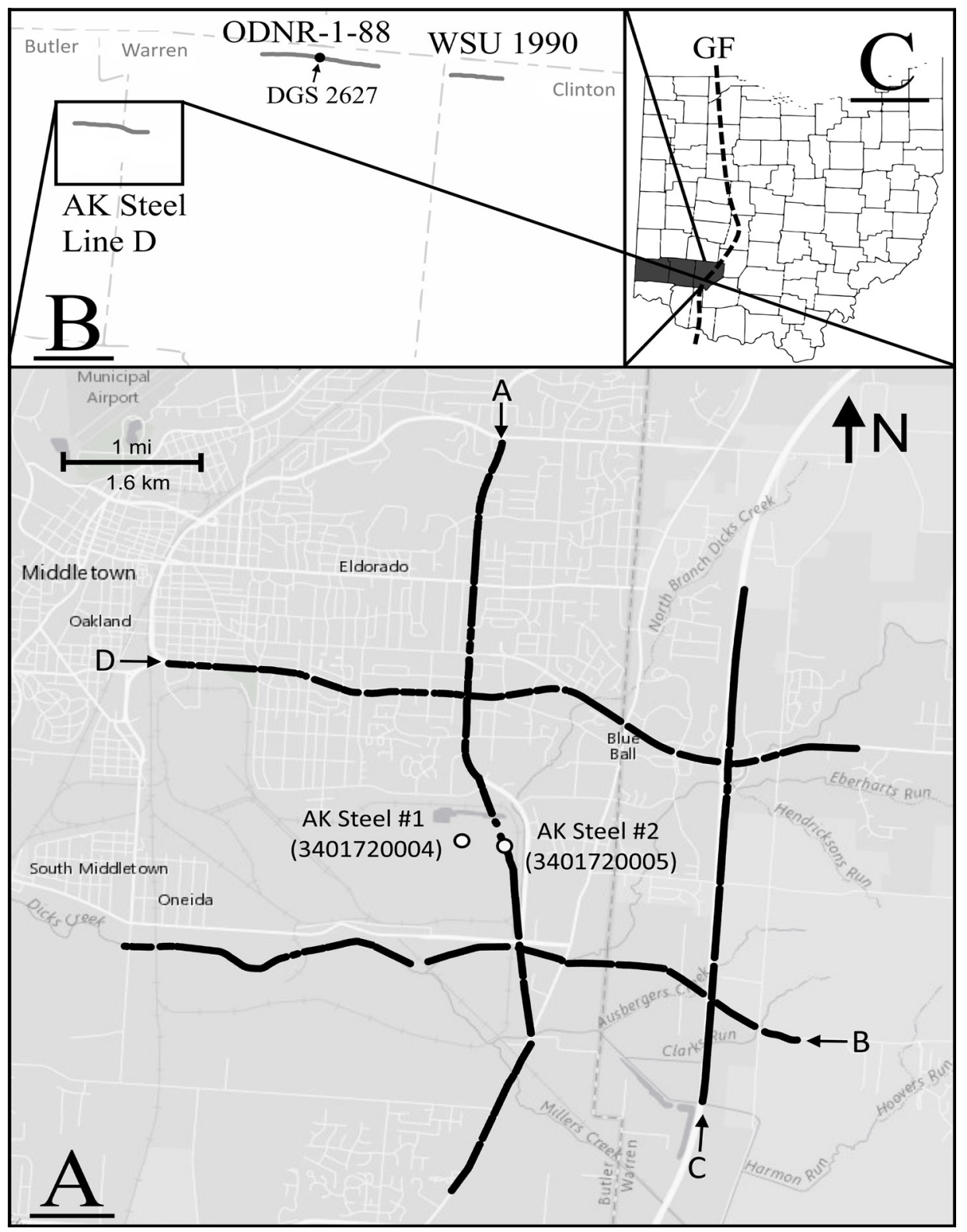

FIGURE 1. (A) Locations of the AK Steel Seismic Lines A, B, C, and D, and AK Steel \#1 and \#2 boreholes (name and API\#) at Middletown, Ohio. Arrows indicate the increasing shot directions. (B) Regional relationship of Seismic Lines ODNR-1-88, WSU 1990, and core hole DGS 2627 to the AK Steel study area with Seismic Line D. (C) Ohio county map showing the Grenville Front (GF) (dashed line) after Kim et al. (2000). 


\section{Tectonic History of the Late Proterozoic}

The Grenville orogeny was one of the major mountain building events in Earth history and culminated in the formation of the supercontinent Rodinia (Van Kranendonk and Kirkland 2013). Crustal remnants of this and related orogens are found globally. Notable exposures on the North American Craton occur in eastern Canada, in the Appalachian Mountains in the form of inliers, in Texas as an exposed uplift, and as inliers in Ireland, Scotland, southern Norway, and Sweden (Gower 1985; Rivers 1997; Davidson 2008; Krabbendam et al. 2017). The term Grenville Province is used to define rocks affected by this event on the North American Craton. In Ohio, the Grenville Province forms the basement in the eastern three-quarters of the state and is recognized by the change of structural fabric and lithologic character. Relatively undeformed felsic rocks of the Eastern GraniteRhyolite Province occur in western Ohio, whereas the metamorphosed and deformed Grenville-age rocks are located to the east (Lucius and Von Frese 1988). The Grenville Front (Fig. 1C) is the structural boundary that marks the western limit of Grenville tectonism and divides these 2 provinces.

In general, the Grenville orogeny was a large, complex, and diachronous event comprised of several deformational cycles. The timing of these cycles, and their relationships within the Grenville orogen, is controversial. Rivers (2008) suggests that prior to the Grenville orogeny, the mid to late Mesoproterozoic Elzevirian (1,245 to 1,220 Ma) and Shawinigan (1,190 to $1,140 \mathrm{Ma}$ ) orogenies took place and are attributed to the accretion of terranes in the southwest Grenville Province. The Grenville orogeny is dated as late Mesoproterozoic to early Neoproterozoic in age and is thought to be a collisional event between Laurentia and another continent (probably Amazonia) (Rivers 2008). The Ottawan orogenic phase (1,090 to 1,020 Ma) is the earlier of 2 phases of the Grenville orogeny and took place in the vicinity of the orogenic core. Afterwards, the younger Rigolet orogenic phase $(1,000$ to $980 \mathrm{Ma})$ took place in the northwestern margin of the craton (McLelland et al. 2010). The orogenic core and the northwestern margin of the craton are separated by the Allochthon Boundary Thrust, a crustal-scale feature (Rivers 2008). The Rigolet-aged Grenville Front Tectonic Zone represents a final contractional pulse that can be observed regionally (McLelland et al. 2010). There is evidence from isotopic dating that suggests this event postdates the Ottawan orogeny and occurred from approximately 995 to $980 \mathrm{Ma}$ (Krogh 1994).

\section{Lithologies Similar to the Middle Run Formation}

In the area of the present study, the AK Steel \#1 borehole (Fig. 1A) encountered a red lithic arenite beneath an apparent angular unconformity (observed in the seismic data) at $986 \mathrm{~m}(3,236 \mathrm{ft})$, with this lithology present to the total depth of the drill hole at $1,004 \mathrm{~m}(3,296 \mathrm{ft})$. The original completion card incorrectly remarked this lithology as rhyolite porphyry, but it is now recognized as a sediment correlative to the Middle Run Formation. The reprocessing of the AK Steel seismic lines in this study attempts to better image the Middle Run Formation and deeper features in these lines, and to relate them to the other seismic data in the area.

Late Mesoproterozoic to early Neoproterozoic red lithic arenites, similar to the Middle Run Formation, are known from several locations around the world. The closest analogues are thought to be the Jacobsville Sandstone in northern Michigan (Shrake 1991) and rocks of the Oronto Group around Lake Superior (Dickas et al. 1992). Both units have been associated with rift fill deposited in the Midcontinent Rift System (Davis and Paces 1990). Drahovzal et al. (1992) and Drahovzal (1997) reported on the Middle Run Formation in the subsurface of central Kentucky and, based on its similarities with the clastics of the Midcontinent Rift System, suggested the Middle Run Formation in Kentucky had similar origins. These lithologic similarities in Kentucky include the occurrence of volcanic rocks (both basaltic and felsic), basaltic flows interbedded with the lithic arenites, and trachyte (Drahovzal et al. 1992; Drahovzal 1997). These similarities led to the interpretation that the Middle Run Formation was deposited in an eastern continuation of the Midcontinent Rift, which was named the East Continent Rift Basin (Drahovzal et al. 1992; Wickstrom et al. 1992; Drahovzal 1997; Stark 1997). There are, however, other occurrences of Mesoproterozoic to early Neoproterozoic lithic arenites of similar age and composition to the Middle Run Formation that occur in the Torridon Group (Applecross Formation $(1.10 \mathrm{Ga})$ ) of Scotland (Rainbird et al. 2001; Krabbendam et al. 2017) 
and the Palmeiral Formation (1.03 Ga), which lies in the southwest Amazonian Craton (Santos et al. 2002). Another occurrence lies within the Llano Uplift of Texas (Spencer et al. 2014). These have all been interpreted as examples of Grenville-derived foreland sequences. However, the Grenville Province in eastern Canada lacks a clear foreland basin (Rainbird et al. 2001; Davidson 2008; Krabbendam et al. 2017), which raises the question previously presented by Moecher et al. (2017a, 2017b)—where is the foreland basin on the North American Craton that should have formed adjacent to one of the largest orogens in Earth history?

\section{METHODS OF SEISMIC ACQUISITION AND REPROCESSING}

\section{Data Acquisition of AK Steel Seismic Lines}

The 4 seismic lines in the AK Steel study area were acquired by Great Lakes Geophysical Inc. (Fig. 1A): Line A (Breiel Blvd.), Line B (shoulder of Greentree Rd. and Oxford State Rd.), Line C (shoulder of northbound I-75), and Line D (Roosevelt Blvd. and OH-122). A roll-on seismic acquisition configuration produced 120-channel split-spread shot gathers resulting in a maximum 60 -fold coverage. Both the receiver station interval and source interval were $25.15 \mathrm{~m}(82.5 \mathrm{ft})$ in length. Receiver arrays consisted of 24 geophones evenly

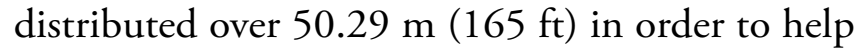
attenuate ground roll. Each shot point consisted of ten, 10-second sweeps by 3 vibroseis trucks sweeping 18 to 100 Hertz, with move-up between sweeps. A DFS-5 (digital field system) seismic recorder sampled the signals at 2 milliseconds (ms) over a 13-second listening time, producing correlated shot gathers with a 3-second record length.

\section{Processing and Analysis of the AK Steel Seismic Data}

The ODNR made the field data, survey information, and observer notes of the AK Steel seismic lines available to Wright State University for reprocessing using ProMax ${ }^{\circledR}$ software. Fig. 2 is a flowchart of the steps employed to reprocess each of the 4 AK Steel seismic lines. Processing steps of particular importance included (1) a relatively large automatic gain control (AGC) operator length (600 $\mathrm{ms})$ to place greater emphasis on higher amplitude events within the window while applying lower relative scaling to smaller amplitude events; (2) the application of 2 separate F-K (frequencywavenumber) filters which attenuated ground-roll, multiple reflections, guided waves, and noise from the operation of the steel plant; and (3) three iterations of residual statics which focused on 2 horizons-a high amplitude continuous coherent reflection at approximately $320 \mathrm{~ms}$ and a pre-Mount Simon Sandstone reflector between 800 and 900 ms. Using a pre-Mount Simon Sandstone reflection for this latter step enhanced the deeper reflections on the seismic sections. Detailed workflows and parameters for these processing techniques are further described by Peterman (2016), together with a complete set of final seismic profiles for each of the AK Steel seismic lines.

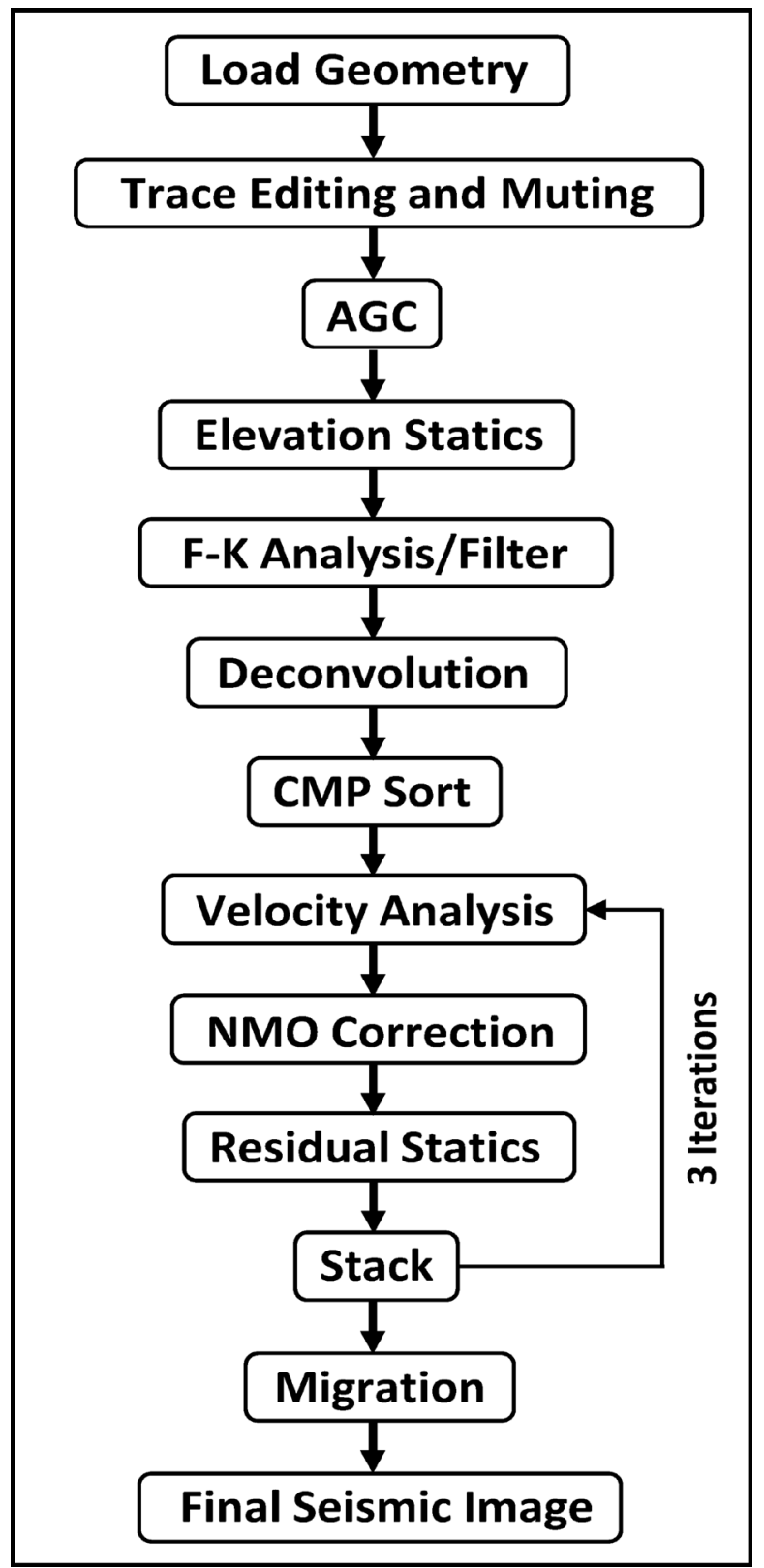

FIGURE 2. Flowchart of steps employed to reprocess all 4 of the AK Steel seismic lines. Note that 3 iterations of velocity analysis and residual statics were performed. 
Sonic, density, and gamma ray log data from the AK Steel \#1 borehole were digitized using NeuraLog ${ }^{\circledR}$, and then tied to the AK Steel seismic profiles using HampsonRussell Geoview software. This allowed the generation of a synthetic trace to correlate identified units in the borehole to reflections in the seismic data. The 2 prominent reflector horizons, identified as " $A$ " and " $B$ " for Fig. 3, were defined by this process. Horizon $A$ is a strong positive reflection within the upper Cambrian Eau Claire Formation, and horizon B indicates the top of the Middle Run Formation (coinciding with the base of the Mount Simon Sandstone, thus delineating the top of the Precambrian basement). Horizon $\mathrm{C}$ is the interpreted base of the Middle Run Formation, which is based upon changes in seismic character only. Below horizon $\mathrm{C}$ there is a thick package of stronger reflections that contrasts with the weak and discontinuous seismic character of the Middle Run Formation.

\section{RESULTS OF SEISMIC REPROCESSING}

The seismic units below the base of the Mount Simon Sandstone on the AK Steel seismic lines exhibit a pattern similar to that observed on the ODNR-1-88 seismic line (Shrake 1991), the latter located northeast of the AK Steel area (Fig. 1B). The Middle Run Formation reflections within the AK Steel and ODNR-1-88 seismic lines are characterized by weak and more discontinuous seismic reflections. Also, the inferred base of the Middle Run Formation (horizon $\mathrm{C}$ on Fig. 3) is defined as lying above a sequence of strong laterally continuous reflections. Beneath the flat-lying Paleozoic sedimentary section in the AK Steel Line D, the Middle Run Formation reflections have a west-southwest dip-resulting in an angular unconformity relationship between the Precambrian Middle Run and overlying upper Cambrian Mount Simon Sandstone formations (for example, see the white box in Fig. 3). The northsouth component of dip was assessed using the $\mathrm{AK}$

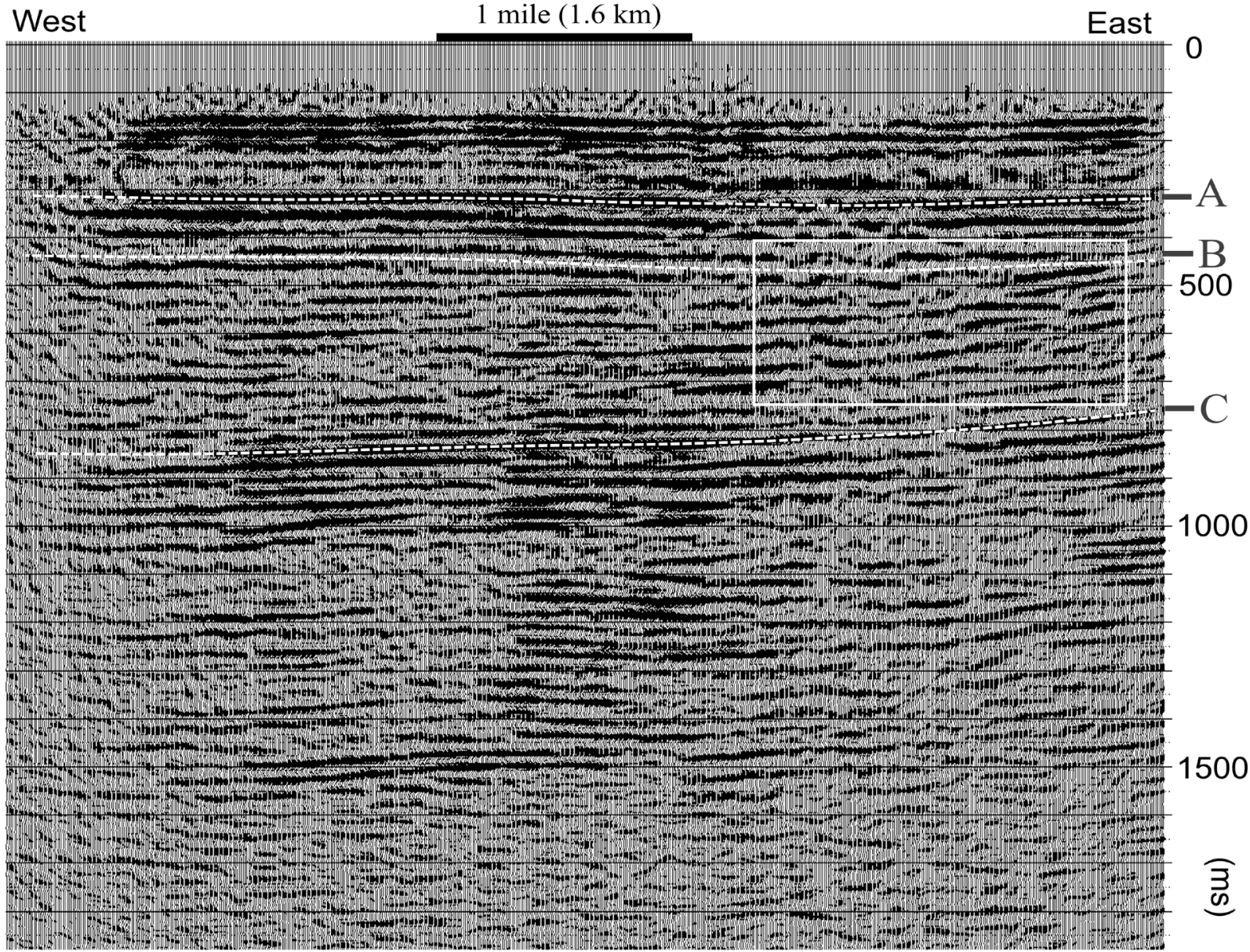

FIGURE 3. The reprocessed AK Steel Seismic Line D showing improved deep-section reflections and key seismic horizons. Location shown on Fig. 1A. Vertical scale in milliseconds (ms). Horizon A: positive amplitude seismic reflection within the Eau Claire Formation used as a residual statics horizon. Horizon B: top of the Precambrian basement (or base of the Cambrian Mount Simon Sandstone). Horizon C: positive amplitude residual statics horizon at the top of a sequence of strong reflections (the interpreted base of the Middle Run Formation). The white box outlines the area exhibiting west-southwest dipping Middle Run Formation strata and the regional angular unconformity relationship with the overlying Mount Simon Sandstone. 
Steel lines oriented in this direction (Lines A and C) (Fig. 1A). The inferred base of the Middle Run Formation (horizon C, Fig. 3) also has this general directional trend, although it appears to exhibit less dip. The time-domain sections of the AK Steel seismic lines were converted to depth using the RMS (root-mean-square) velocities determined through velocity analysis. Calculations suggest that the Middle Run Formation is approximately 670 and $1,128 \mathrm{~m}$ $(2,200$ and 3,700 ft $)$ thick at the eastern and western margin of the AK Steel area, respectively.

\section{DISCUSSION}

\section{Interpretation of the Seismic Transect of the Grenville Foreland Basin in Southwest Ohio}

Fig. 4 is a composite east-west trending profile of the AK Steel D, ODNR-1-88 (Shrake 1991), and WSU 1990 (Wolfe et al. 1993) seismic lines. This figure is accompanied by an interpretative illustration of lithologic boundaries and structures in the seismic profiles; interpolated elements are shown within the gaps between each profile. The Middle Run Formation, as noted by Shrake (1991), is identified on these seismic lines as an interval of relatively weak and discontinuous seismic character that is underlain by a sequence of laterally continuous strong reflections. This meager reflection quality of the Middle Run Formation is likely due to lithologic homogeneity (Shrake et al. 1990; Shrake 1991; Drahovzal et al. 1992) and the lack of considerable contrasts of acoustical impedance between strata.
The Middle Run depositional basin-in the vicinity of the AK Steel lines-dips gently westsouthwest, is relatively deep (670 to $1,128 \mathrm{~m} ; 2,200$ to $3,700 \mathrm{ft}$ ), and is underlain by a series of continuous high-impedance reflections about 800 to $1,100 \mathrm{~ms}$ in depth (Fig. 3). In contrast - within the ODNR-1-88 line-the Middle Run Formation has a moderate dip eastward, with pre-Mount Simon-age erosion creating an angular unconformity observed below the Mount Simon Sandstone at the west end of the line. The change in dip and thickness of the Middle Run Formation between ODNR-1-88 and AK Steel Line $\mathrm{D}$ (Fig. 4) suggests the presence of a reverse fault in the intervening interval with an estimated vertical displacement of about $792 \mathrm{~m} \mathrm{(2,600} \mathrm{ft).} \mathrm{Seismic}$ Line WSU 1990 (Wolfe et al. 1993), eastward of the ODNR-1-88 line (Figs. 1B and 4), is closer to the Grenville Front (Fig. 1C) and helps contextualize the deformational setting of the pre-Mount Simon Sandstone. The Middle Run Formation (and the underlying sequence of strong reflections) displays the eastern flank of a west-verging asymmetric syncline cut by reverse faults. These compressional features, along with the reverse fault interpreted in Line ODNR-1-88, suggest a consistent, westwardly directed, compressional tectonic stress adjacent to the Grenville Front.

\section{Age and Provenance of the Middle Run Formation}

The red lithic arenite in the area of the AK Steel seismic lines is interpreted to correlate with the

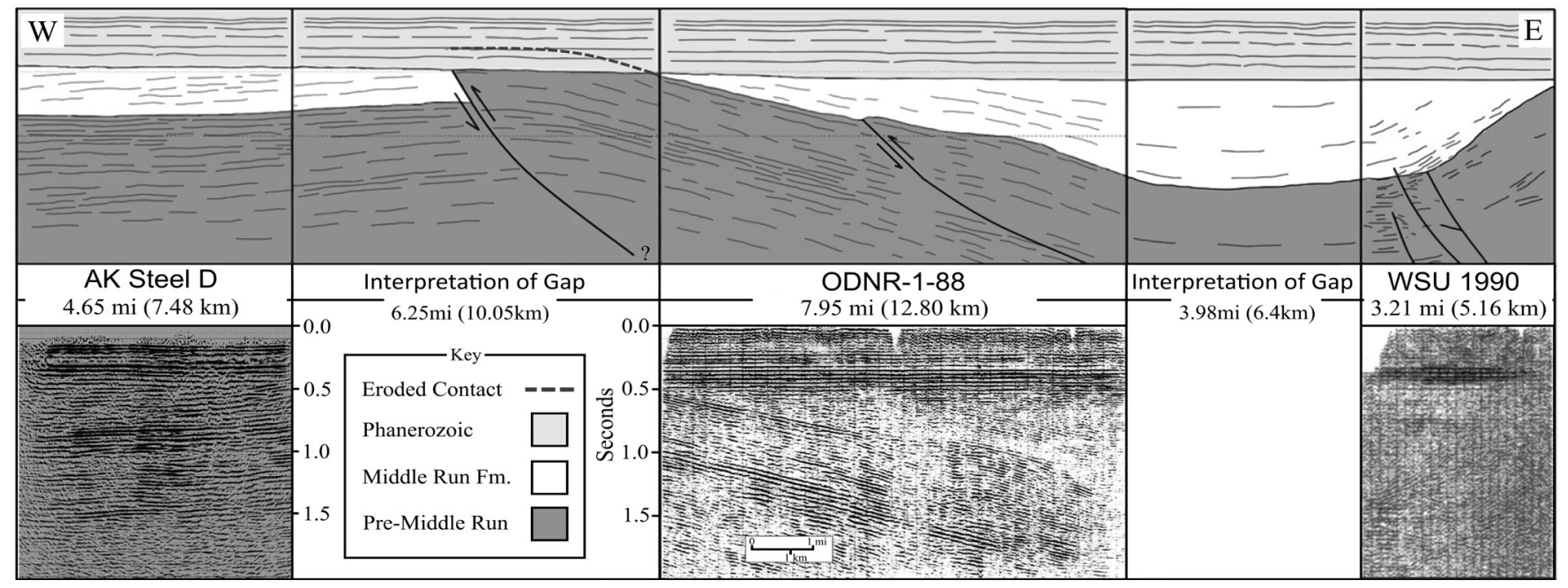

FIGURE 4. Scaled Seismic Lines AK Steel D, ODNR-1-88, and WSU 1990. Line drawing illustrating interpreted lithologic boundaries with structural features and inferred relationship between seismic profiles. Seismic Line ODNR-1-88 is modified from Drahovzal (1997) and WSU 1990 is adapted from Wolfe et al. (1993). 
Middle Run Formation as defined in the stratotype at core DGS 2627 (Shrake 1991). Santos et al. (2002) determined-using detrital zircon geochronology of samples from core DGS 2627-that the Middle Run Formation had a maximum age of $1,048 \pm 22 \mathrm{Ma}$. A possible minimum age of $700 \mathrm{Ma}$ is suggested by fission track dating from samples of the same core (Roden-Tice and Shrake 1998); however, Santos et al. (2002) believe this was reset by a heating event. Additionally, organic-walled microfossils in the DGS 2627 core are similar in morphology to fossils found in Proterozoic rocks worldwide (Richardson 2015). The ages of these similar worldwide fossil assemblages agree well with the age range of 1,048 to $700 \mathrm{Ma}$, determined by Santos et al. (2002) and Roden-Tice and Shrake (1998), for the Middle Run Formation.

Sedimentary structures and lithologies within the Middle Run Formation, described by Shrake (1991), suggest an arid fluvial depositional environment with sediments derived from a recycled orogen-with some affinities to a dissected or transitional arc. Santos et al. (2002) note that the majority of the Middle Run Formation appears to have been derived from rocks of the Grenville orogen. They found that about 80 to 90 percent of the detrital zircons in the portion of the Middle Run Formation sampled were probably formed within the Laurentian margin and the Frontenac-Adirondack Belt, suggesting the primary source of the Middle Run sediments originated from Grenville rocks exposed to the east (with only minor sediment input derived from the Granite-Rhyolite Province to the west of core DGS 2627). Prior workers (Drahovzal et al. 1992; Hauser 1993; Wolfe et al. 1993) acknowledge the potential presence of older clastic rocks within the broader Eastern Granite-Rhyolite Province.

Drahovzal et al. (1992) proposed that the Middle Run Formation was deposited during an episode of rifting in the East Continent Rift Basin (analogous to the Keweenawan Rift). This scenario is based on the lithologic similarities between the Middle Run Formation and the other red lithic arenites of the midcontinent region that are associated with rift fill (e.g., the Jacobsville Sandstone (Shrake 1991) and Oronto Group (Dickas et al. 1992)). Drahovzal et al. (1992) and Drahovzal (1997) interpreted a lithic arenite in central Kentucky as the Middle Run Formation, which was deposited in the proposed East Continent Rift Basin and later deformed by the Grenville orogeny. However, the major events of
Keweenawan Rift development and magmatism are thought to have occurred between 1,109 to 1,094 Ma (Davis and Paces 1990). This is older than the maximum age of zircons in the Middle Run sediments in southwest Ohio $(1,048 \pm 22 \mathrm{Ma}$ ) (Santos et al. 2002) (Fig. 5) and does not support deposition of Middle Run sediments in a Keweenawan-age equivalent East Continent Rift Basin. It is possible that the Middle Run Formation equivalent rocks in Kentucky have been stripped by erosion and deeper, earlier, rift sediments may be preserved in this area.

Alternatively, Hauser (1993, 1996), Santos et al. (2002), Baranoski et al. (2009), Moecher et al. (2017a, 2017b), and Peterman et al. (2017) proposed that the Middle Run Formation in southwest Ohio was deposited in a foreland basin during Grenville uplift and exhumation. Late Mesoproterozoic to early Neoproterozoic lithic arenites known from Scotland, the southwest Amazonian Craton, and the Llano Uplift of Texas (Rainbird et al. 2001; Santos et al. 2002; Spencer et al. 2014; Krabbendam et al. 2017) are similar in composition and age to the Middle Run Formation; each has been interpreted as having been deposited in a Grenville foreland basin. Furthermore, the zircon geochronology of basement cores from Kentucky show a similar disparity between the age of its lithic arenites and the East Continent Rift ages (Moecher et al. 2017b), supporting deposition in the Grenville foreland basin. The origin of pre-Mount Simon-age lithic arenites, however, is complicated by the absence of Grenville geochronological signatures in some areas (Clay and Moecher 2018; Clay et al. 2019) that favor early syn-rift basin fill (Drahovzal et al. 1992; Drahovzal 1997).

Ascenario potentially reconciling these competing tectonic interpretations was posed by Hauser (1996). Hauser suggested that the Grenville Front in Ohio may have reactivated and overprinted preexisting Keeweenawan Rift related crustal structures, but with the development of a Grenville foreland basin represented by the Middle Run Formation lithic arenite. Consequently, sedimentary sequences below the Middle Run Formation may be related to preGrenville deposition.

\section{Tectonic Setting and Timing}

The Ottawan phase (1,090 to $1,020 \mathrm{Ma})$ of the Grenville orogeny was most likely responsible for exhuming the main source area supplying sediments to the Middle Run Formation. This timing agrees 
well with (1) the detrital zircon dates obtained from the Middle Run Formation by Santos et al. (2002), (2) the age and lithology of localities with similar Grenville-derived lithic arenites (Rainbird et al. 2001; Santos et al. 2002; Krabbendam et al. 2017; Moecher et al. 2017a, 2017b), and (3) the occurrence of distinctive organic-walled microfossils in the Middle Run Formation and other Neoproterozoic rocks (Richardson 2015). The age, thickness, structural style of deformation, and proximity of the Middle Run Formation to the Grenville Front in southwest Ohio all support the interpretation that the Middle Run Formation was deposited in a foreland basin deformed by subsequent Grenville tectonism. Also, the Middle Run Formation and the underlying pre-Middle Run units were deformed after the events of the Ottawan phase of the Grenville orogeny. This deformation formed the asymmetric syncline and reverse faults on the WSU 1990 seismic line, the minor reverse fault on the ODNR-1-88 seismic line, and the reverse fault inferred to exist between ODNR-1-88 and the AK Steel lines (Fig. 4).

This post-Ottawan phase of deformation was apparently related to the development of the Grenville Front Tectonic Zone at the western margin of the Grenville Province, as thrust faults may have rapidly propagated westward into the craton at the end of the Grenville orogeny (Hauser 1993). Additionally, U-Pb dating by Krogh (1994) shows that compression of the Grenville Front occurred between 995 to 980 $\mathrm{Ma}$. The age ranges for these tectonic events - and possible depositional range for the Middle Run Formation-are presented in Fig. 5.

Although the interpretation of a Grenville-age reverse fault between the AKSteel lines and ODNR1-88 depends upon the correlation of the preMiddle Run reflector packages, this interpretation is consistent with the style of deformation seen on the other seismic lines evaluated.

Alternative interpretations must be considered, however, as a more complicated stratal geometry and deformational history could also explain this structural relationship. A normal fault is possible, but contrasts with the compressional features observed in ODNR-1-88 and WSU 1990. The top of the Middle Run Formation is an unconformity, which could cause differences in the thickness and vertical position of the top of this unit. An anticline is another possibility if its apex is close to the western margin of ODNR-1-88. The acquisition of additional seismic data between ODNR-1-88 and the AK Steel seismic lines are necessary to illuminate the true subsurface structure.

\section{CONCLUSIONS}

Reprocessed AK Steel seismic reflection lines in southwest Ohio, interpreted together with nearby Seismic Lines ODNR-1-88 (Shrake 1991) and WSU 1990 (Wolfe et al. 1993), indicate that the Middle Run Formation varies from about 670 to $1,128 \mathrm{~m}$ $(2,200$ to $3,700 \mathrm{ft})$ in thickness under the AK Steel area. Northeast of the AK Steel area, the Middle Run Formation is absent at the western margin of ODNR-1-88 due to the steeply east-dipping preMount Simon Sandstone units. A reverse fault with a vertical displacement of about $792 \mathrm{~m}(2,600 \mathrm{ft})$ is interpreted to exist in the gap between the AK Steel and ODNR-1-88 seismic lines. This inferred fault, along with structures observed on the ODNR-1-88 and WSU 1990 seismic line to the east, exhibit a

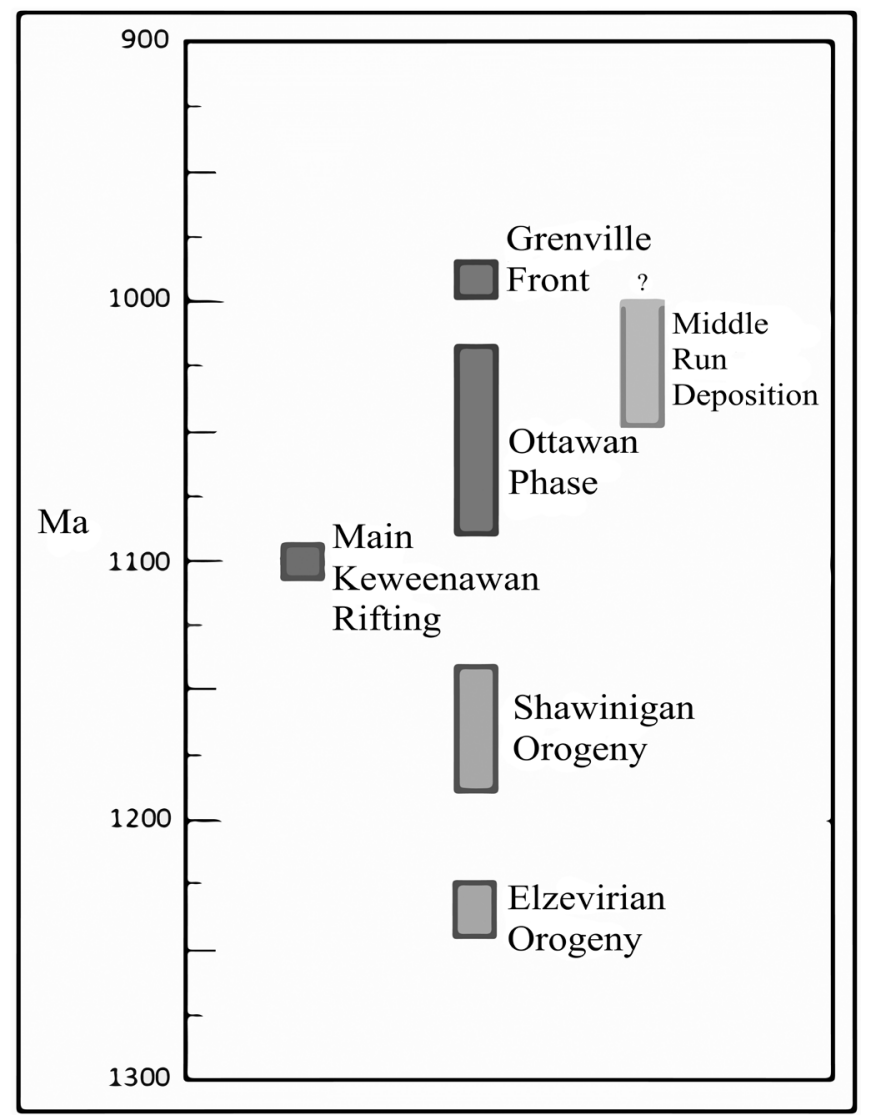

FIGURE 5. Chronology of deformational and depositional events affecting Precambrian rock in the eastern United States. The possible range for the deposition of the Middle Run Formation is unknown due to the Mount Simon unconformity, yielding no definitive upper limit. 
west-verging asymmetric faulted syncline developed in proximity to the Grenville Front.

The Middle Run Formation sediments are thought to be as old as $1,048 \pm 22 \mathrm{Ma}$ (Santos et al. 2002) and derived from uplands developed during the Ottawan phase (1,090 to 1,020 Ma) (Rivers 2008) of the Grenville orogeny. Similar geochronological studies in Ohio and the surrounding area do not favor a syn-rift basin fill interpretation for this unit (Moecher et al. 2017a, 2017b).

The thickness, sedimentary provenance, age, sedimentologic similarities with other Grenvillian lithicarenites, and consistentwestward compressional structural style in proximity to the Grenville Front all serve to reinforce the interpretation that the Middle Run Formation in southwest Ohio was deposited in a Grenville foreland basin that was later deformed by the Grenville Front compressional event (995 to $980 \mathrm{Ma}$ ) (Krogh 1994).

\section{LITERATURE CITED}

Baranoski MT. 2002. Structure contour map on the Precambrian unconformity surface in Ohio and related basement features. Columbus (OH): Ohio Department of Natural Resources, Division of Geological Survey. Map PG-23, scale 1:500,000, 1 sheet: color, accompanying 18 p. text.

https://ohiomemory.org/digital/collection/p267401ccp2/id/473

Baranoski MT, Dean SL, Wicks JL, Brown VM. 2009. Unconformity-bounded seismic reflection sequences define Grenville-age rift system and foreland basins beneath the Phanerozoic in Ohio. Geosphere. 5(2):140-151.

https://doi.org/10.1130/GES00202.1

Clay JM 3rd, Moecher DP. 2018. Detrital zircon U-Pb geochronology of the Middle Run sequence in Kentucky and Ohio supports the spatiotemporal convergence of late Mesoproterozoic Grenville collisional and midcontinent rifting processes, and the presence of a late Grenville foreland basin under central KY. Geological Society of America Annual Meeting; 2018 Nov 4; Indianapolis (IN). Boulder (CO): Geological Society of America. Session No. 68. GSA Abstracts with Programs 50(6).

https://doi.org/10.1130/abs/2018AM-322907

Clay JM 3rd, Moecher DP, Bowersox JR. 2019. Insights into the interaction of Grenville orogenesis and midcontinent rifting from new detrital zircon U-Pb geochronology of the Middle Run sequence in subsurface Kentucky and Ohio. Southeastern Section, 68th Annual Meeting, Geological Society of America; 2019 Mar 29; Charleston (SC). Boulder (CO): Geological Society of America. Session No. 34. GSA Abstracts with Programs 51(3). https://doi.org/10.1130/abs/2019SE-326457

Davidson A. 2008. Late Paleoproterozoic to mid-Neoproterozoic history of northern Laurentia: an overview of central Rodinia. Precambrian Res. 160(1-2):5-22.

https://doi.org/10.1016/j.precamres.2007.04.023
Davis DW, Paces JB. 1990. Time resolution of geologic events on the Keweenaw Peninsula and implications for development of the Midcontinent Rift System. Earth Planet Sc Lett. 97(1-2):54-64. https://doi.org/10.1016/0012-821X(90)90098-I

Dickas AB, Mudrey MG, Ojakangas RW, Shrake DL. 1992. A possible southeastern extension of the Midcontinent Rift System located in Ohio. Tectonics. 11(6):1406-1414. https://doi.org/10.1029/91TC02903

Drahovzal JA. 1997. Proterozoic sequences and their implications for Precambrian and Cambrian geologic evolution of western Kentucky: evidence from seismic-reflection data. Seismol Res Lett. 68(4):533-566. https://doi.org/10.1785/gssrl.68.4.553

Drahovzal JA, Harris DC, Wickstrom LH, Walker D, Baranoski MT, Keith B, Furer LC. 1992. The East Continent Rift Basin: a new discovery. Lexington (KY): Kentucky Geological Survey. 25 p. Special Publication 18, Series XI. Separately published by both the Ohio Department of Natural Resources, Division of Geological Survey (Information Circular 57) and the Indiana Geological Survey (Special Report 52).

https://kb.osu.edu/handle/1811/80394

Gower CF. 1985. Correlations between the Grenville Province and Sveconorwegian Orogenic Belt-implications for Proterozoic evolution of the southern margins of the Canadian and Baltic Shields. In: Tobi AC, Touret JLR, editors. The deep Proterozoic crust in the North Atlantic Provinces. NATO ASI series (ASIC, volume 158). Dordrecht (NL): D. Reidel (now Springer). p. 247-257. https://doi.org/10.1007/978-94-009-5450-2_15

Hauser EC. 1993. Grenville foreland thrust belt hidden beneath the eastern U.S. midcontinent. Geology. 21(1):61-64. https://doi.org/10.1130/0091-7613(1993)021<0061:GFTBHB>2.3.CO;2

Hauser EC. 1996. Midcontinent rifting in a Grenville embrace. In: van der Pluijm BA, Catacosinos PA, editors. Basement and basins of eastern North America. Geological Society of America, Special Paper 308. Boulder (CO): Geological Society of America. p. 67-75. https://doi.org/10.1130/0-8137-2308-6.67

Kim JW, von Frese RRB, Kim HR. 2000. Crustal modeling from spectrally correlated free-air and terrain gravity data-a case study of Ohio. Geophysics. 65(4):1057-1069. https://doi.org/10.1190/1.1444799

Krabbendam M, Bonsor H, Horstwood MSA, Rivers T. 2017. Tracking the evolution of the Grenvillian foreland basin: constraints from sedimentology and detrital zircon and rutile in the Sleat and Torridon Groups, Scotland. Precambrian Res. 295:67-89. https://doi.org/10.1016/j.precamres.2017.04.027

Krogh TE. 1994. Precise U-Pb ages for Grenvillian and pre-Grenvillian thrusting of Proterozoic and Archean metamorphic assemblages in the Grenville Front tectonic zone, Canada. Tectonics. 13(4):963-982. https://doi.org/10.1029/94TC00801

Lucius JE, Von Frese RRB. 1988. Aeromagnetic and gravity anomaly constraints on the geology of Ohio. Geol Soc Am Bull. 100(1):104-116.

https://doi.org/10.1130/0016-7606(1988)100<0104:AAGACO>2.3.CO;2 
McLelland JM, Selleck BW, Bickford ME. 2010. Review of the Proterozoic evolution of the Grenville Province, its Adirondack outlier, and the Mesoproterozoic inliers of the Appalachians. In: Tollo RP, Bartholomew MJ, Hibbard JP, Karabinos PM, editors. From Rodinia to Pangea: the lithotectonic record of the Appalachian region. Geological Society of America, Memoir 206. Boulder (CO): Geological Society of America. p. 1-29.

https://doi.org/10.1130/2010.1206(02)

Moecher DP, Bowersox JR, Hickman JB. 2017a. Is the east continent rift basin really a rift basin, or is it a foreland basin? And did the Grenville orogeny 'take a breather' during midcontinent rifting? New evidence from zircon $\mathrm{U}-\mathrm{Pb}$ geochronology of the Middle Run Fm. and basement orthogneiss in drill core from Kentucky. Joint 52nd Northeastern Annual Section / 51st North-Central Annual Section Meeting, Geological Society of America; 2017 Mar 19; Pittsburgh (PA). Boulder (CO): Geological Society of America. Session No. 18. GSA Abstracts with Programs 49(2).

https://doi.org/10.1130/abs/2017NE-290355.

Moecher DP, Bowersox JR, Hickman JB. 2017b. Zircon U-Pb geochronology of two basement cores (Kentucky, USA): implications for Late Mesoproterozoic sedimentation and tectonics in the eastern midcontinent. J Geol. 126(1):25-39. https://doi.org/10.1086/694825

Peterman DJ. 2016. Seismic reflection profiling near Middletown, Ohio and interpretation of Precambrian deformational settings [master's thesis]. [Dayton $(\mathrm{OH})]$ : Wright State University. 98 p. https://corescholar.libraries.wright.edu/etd_all/1495

Peterman DJ, Watts DR, Hauser EC, Parent AM. 2017. Seismic profiling near Middletown, Ohio: an interpretation of pre-Mt. Simon deformational history in the eastern midcontinent. Joint 52nd Northeastern Annual Section / 51st North-Central Annual Section Meeting, Geological Society of America; 2017 Mar 19; Pittsburgh (PA). Boulder (CO): Geological Society of America. Session No. 18. GSA Abstracts with Programs. 49(2). https://doi.org/10.1130/abs/2017NE-290505

Rainbird RH, Hamilton MA, Young GM. 2001. Detrital zircon geochronology and provenance of the Torridonian, NW Scotland. J Geol Soc London. 158(1):15-27. https://doi.org/10.1144/jgs.158.1.15

Richardson JG. 2015. Organic microfossils of the Middle Run Formation (Neoproterozoic?) of Ohio, U.S.A. Northeastern Geoscience. 33:34-40.

Rivers T. 1997. Lithotectonic elements of the Grenville Province: review and tectonic implications. Precambrian Res. 86(3-4):117-154. https://doi.org/10.1016/S0301-9268(97)00038-7
Rivers T. 2008. Assembly and preservation of lower, mid, and upper orogenic crust in the Grenville Province-implications for the evolution of large hot long-duration orogens. Precambrian Res. 167(3-4):237-259. https://doi.org/10.1016/j.precamres.2008.08.005

Roden-Tice MK, Shrake DL. 1998. Age of the Middle Run Sandstone underlying Warren County, Ohio. Boulder (CO): Geological Society of America. GSA Abstracts with Programs 30(2). p. 69.

Santos JOS, Hartmann LA, McNaughton NJ, Easton RM, Rea RG, Potter PE. 2002. Sensitive high resolution ion microprobe (SHRIMP) detrital zircon geochronology provides new evidence for a hidden Neoproterozoic foreland basin to the Grenville orogen in the eastern Midwest, U.S.A. Can J Earth Sci. 39(10):1505-1515.

https://doi.org/10.1139/e02-052

Shrake DL. 1991. The Middle Run Formation: a subsurface stratigraphic unit in southwestern Ohio. Ohio J Sci. 91(1):49-55.

http://hdl.handle.net/1811/23429

Shrake DL, Wolfe PJ, Richard BH, Swinford EM, Wickstrom LH, Potter PE, Silter GW. 1990. Lithologic and geological description of a continuously cored hole in Warren County, Ohio, including description of the Middle Run Formation (Precambrian?) and a seismic profile across the core site. Columbus (OH): Ohio Department of Natural Resources, Division of Geological Survey. 11 p., 2 fold-out plates. Division of Geological Survey, Information Circular No. 56. http://hdl.handle.net/1811/80393

Spencer CJ, Prave AR, Cawood PA, Roberts NMW. 2014. Detrital zircon geochronology of the Grenville/Llano foreland and basal Sauk Sequence in west Texas, USA. Geol Soc Am Bull. 126(7-8):1117-1128. https://doi.org/10.1130/B30884.1

Stark TJ. 1997. The East Continent Rift Complex: evidence and conclusions. In: Ojakangas RW, Dickas AB, Green JC, authors. Middle Proterozoic to Cambrian rifting, central North America. Boulder (CO): Geological Society of America. GSA Special Paper 312. p. 253-266. https://doi.org/10.1130/0-8137-2312-4.253

Van Kranendonk MJ, Kirkland CL. 2013. Orogenic climax of Earth: the 1.2-1.1 Ga Grenvillian superevent. Geology. 41(7):735-738. https://doi.org/10.1130/G34243.1

Wickstrom LH, Drahovzal JA, Keith BD. 1992. The geology and geophysics of the East Continent Rift Basin: report of Cincinnati Arch Consortium. Indiana Geological Survey, Open File Study 92-04, 103 p.

Wolfe PJ, Richard BH, Potter PE. 1993. Potential seen in Middle Run basins of western Ohio. Oil Gas J. 91(14):68-73. 